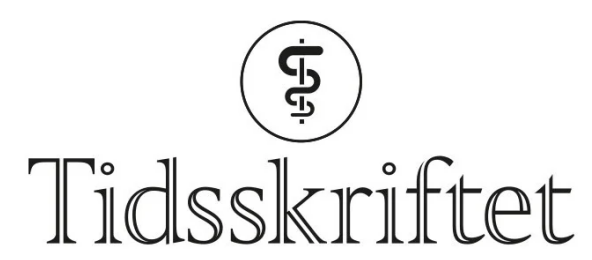

DEN NORSKE LEGEFORENING

\title{
Arne F. Nordøy
}

\author{
MINNEORD
}

HELGE STALSBERG

KNUT RASMUSSEN

ROLF SELJELID

JARLE AARBAKKE

KNUT E. SCHRØDER

Professor Arne F. Nordøy døde 24.7.2020. Med dette er en pioner ved Universitetet i Troms $\emptyset$ - Norges arktiske universitet og Universitetssykehuset Nord-Norge gått bort.

Arne ble født i Troms $ø$ i 1933 og var hele livet en stor Nord-Norge-patriot. Han tok medisinsk embetseksamen i Bergen i 1957, doktorgrad i 1965 på faktorer som påvirker

trombosedannelse og ble i 1971 den første dekanus ved det medisinske fakultet ved det nye Universitetet i Tromsø. Han etablerte landets første helseksjonerte medisinske avdeling.

Arne hadde en unik rolle i universitetets historie. Han koblet sammen

Kulturdepartementet og Peter F. Hjort, som startet planleggingen av universitetet, før han selv overtok stafettpinnen og gjennomførte planene. Hans mest betydelige rolle var som inspirator og rekrutterer av en rekke nøkkelpersoner til Tromsøs universitet og sykehus. Mange av dem er der ennå.

I de første årene var det en rekke helsepolitiske og universitetspolitiske kamper mellom nord og sør, og Arne skapte respekt for den skjøre planten i nord. Han maktet mot store odds å finansiere den første Tromsø-undersøkelsen, som senere ble avgjørende for den vitenskapelige utviklingen ved Det helsevitenskapelige fakultet.

Selv fortsatte han livet ut å forske på lipider og trombose. Han hadde fire forskningsopphold i USA og ett i Frankrike. Han publiserte ca. 140 vitenskapelige artikler. Til tross for lukrative tilbud fra utenlandske universitet ble han værende i Tromsø. Han var 
sterkt opptatt av det som kommer etter ham, og forskningsarven blir videreført av TRECsenteret ved universitetet.

Arne var ridder av St. Olavs Orden, en avholdt lege og en karismatisk underviser. Hans engasjement for Tromsøs eldre befolkning førte til et forslag om å etablere et senter for behandling og forskning for denne gruppen på St. Elisabeths hotell og helsehus. Dessverre klarte han denne gangen ikke å mobilisere nok støtte.

Bak alt dette lå Arnes smittende entusiasme. Han var stolt og glad over at hans tre døtre alle gjorde en god innsats i helsevesenet. Han var sosial og gjestfri og alltid i godt humør. Det gjaldt helt inn i den siste fasen av livet, da en stor svulst ikke lot seg stoppe.

For oss var Arne en nær venn og kollega gjennom alle år. Han samlet oss i «Arnes syklubb», der vi som pensjonister kunne se tilbake på det vi hadde deltatt i. Arne vil bli dypt savnet, men klubben vil bestå.

Like før Peter F. Hjort døde, spurte Arne ham om hvorfor han hadde satset alt på Tromsø. Hjorts svar var ett ord: «rettferdighet». Dette svaret kunne like gjerne vært Arnes eget.

Vi er takknemlige for å ha vært Arnes venner.

Publisert: 12. oktober 2020. Tidsskr Nor Legeforen. DOI: 10.4045/tidsskr.20.0728

(C) Tidsskrift for Den norske legeforening 2023. Lastet ned fra tidsskriftet.no 26. april 2023. 